\title{
The Sources of Industrial Growth in Indonesia, 1985-1995: An Input-Output Analysis
}

\author{
Takahiro Akita \\ and \\ Agus Hermawan \\ Working Paper No.4 \\ June 2000
}

Takahiro Akita is Professor in the Graduate School of International Relations, International University of Japan, Niigata, Japan.

The Authors are grateful to the International University of Japan and the Ministry of Education (under grant No. 12630073) for their financial support. We would also like to thank anonymous referees for their helpful comments.

Agus Hermawan is with the Ministry of Finance in Indonesia. 


\begin{abstract}
This paper analyzes structural changes and the sources of industrial growth in Indonesia between 1985 and 1995 by using the 1985, 90, and 95 input-output tables. It also investigates the changes in the pattern of industrial growth over the 25 -year period from 1971-95. In the past three decades, Indonesia appears to have achieved a successful transition from an inward-looking, government-led industrialization financed by oil exports to an outward-looking, market-oriented industrialization based on non-oil exports, in which the turning period was during the 1980-85 period. During 1985-95, the expansion of household consumption remained the main source of output growth as it accounted for about one-half of total output growth; in contrast, the contribution of government consumption was reduced to a negligible level, signifying the declining role of the government sector in output growth. The expansion of exports was also a key factor in output growth in addition to the rise in export-oriented investments. It is noteworthy that export expansion was made, to a large extent, by non-oil exports, rather than oil exports.
\end{abstract}




\section{Introduction}

Indonesia, as a developing country, has been formulating industrial development strategies since the late 1960s through five-year development plans (REPELITAs), which detail the goals and steps for each phase of the country's development process. Each REPELITA focuses on different aspects of industrial development due to the varying conditions at the beginning of each five-year period. The previous REPELITA, of course, forms a guideline for the subsequent REPELITA. For example, REPELITA I, during the early industrialization period, emphasized industries that support agriculture through backward and forward linkages. REPELITA II, in contrast, stressed industries that maximize employment creation. In sum, the long-term purpose of industrial development is to establish a stronger and more balanced economic structure that includes advanced industrial sectors sustained by viable agriculture sectors.

At the early stage of industrialization, Indonesia employed import-substituting industrialization in order to stimulate manufacturing industries, especially consumer goods industries. The government controlled imports by imposing high tariffs and non-tariff barriers to protect domestic production. These efforts were the main drivers of the industrial and Gross Domestic Product (GDP) growth rates. The average annual growth rates of manufacturing value added and GDP were 15 percent and 7.5 percent in the 1970s, respectively. This rapid industrial growth was brought about by a large expansion of domestic demand, which was supported by a massive inflow of foreign exchange due to increasing oil exports. Unfortunately, the government did not pay much attention to the relatively small and easily saturated domestic market. Therefore, when oil prices fell in 1982 and domestic demand dropped, the annual average growth rate of GDP decreased markedly to only 4 percent per year from 1982-85.

The decline in oil prices in the 1980s encouraged the government to adopt exportoriented industrialization. Several deregulation measures were introduced to raise non-oil and gas exports. These measures were quite effective in changing the structure of the Indonesian economy. Before the 1980s, the oil and gas sectors constituted more than 70 percent of total exports. However, by the early 1990s, the contribution of the oil and gas 
sectors decreased to less than 30 percent of total exports, while the manufacturing share increased to more than 50 percent. In the late 1980s and the early 1990s, Indonesia achieved an average annual GDP growth rate of more than 6 percent, comparable to the rapid growth period of the 1970s. However, this rapid growth rate was achieved without the benefit of extensive oil revenue windfalls.

Many researchers have analyzed industrialization and structural changes in Indonesia. Poot et al. (1990) examined Indonesia's industrialization patterns and policies during the 1970s and the early 1980s. James and Fujita (1989), Poot (1991), and Akita (1991) investigated the sources of industrial growth in the 1970s and the early 1980s using the national input-output (I-O) tables. This paper builds upon the study by Akita (1991). Specifically, it analyzes structural changes and the sources of industrial growth in Indonesia between 1985 and 1995 by using the growth-factor decomposition method. It also examines the changes in the pattern of industrial growth over the 25 -year period from 1971-95, by combining this study's results with the results of Akita (1991), which had examined the growth patterns from 1971-85.

The paper is organized as follows. Section two provides an overview of Indonesia's economic policies between 1985 and 1995. It details the policy guidelines of two REPELITAs and the accompanying reform measures. Section three discusses the data sources and the research methodology. Section four analyzes the structural changes and the sources of industrial growth. Section five presents a summary of the major findings.

\section{Industrial and Trade Policies from 1985-95}

Since this study analyzes industrial development during the period that corresponds most closely to REPELITA IV (1984/1985 - 1988/1989) and V (1989/1990 - 1993/1994), it is necessary to discuss the policies of these two REPELITAs and the subsequent reform measures used in achieving the policy objectives of this period.

REPELITA IV had the following policy guidelines for industrial development (Republic of Indonesia, 1984):

1. To build a robust and more balanced national economic structure.

2. To develop linkages between small, medium, and large industries. 
3. To encourage small-scale industries to play a more significant role in solving employment problems and to increase their processing capabilities to generate higher value added.

4. To raise awareness of the role of technology in industrial development.

5. To give high priority to increasing manufactured exports.

Similarly, REPELITA $\mathrm{V}$ had the following policy guidelines for industrial development (Republic of Indonesia, 1989).

1. To develop export-oriented industries to increase foreign exchange earnings and to promote diversification of manufactured products.

2. To deepen and to strengthen the industrial structure, particularly in activities with strong inter-industry linkages.

3. To develop small-scale industries to enhance business and employment opportunities, to achieve a more equitable distribution of income, and to accelerate economic growth in relatively backward areas.

4. To expand food-processing industries to further optimize forward linkages for the agricultural sector, to increase value added, and to strengthen the economic structure.

5. To promote appropriate technologies.

In 1985, the government began introducing several reform measures in order to enhance the international competitiveness of manufactured goods. ${ }^{1}$ The initial step included the rationalization of the tariff system in March 1985 that compensated for the value-added tax introduced in 1984. This was followed by Presidential Instruction No.4 in April 1985, in which the government shortened the export license processing time by curtailing the discretionary actions of customs officials, long known as a major source of a high cost-economy. A private surveyor for inspecting commodities at the point of entry was also hired.

The sharp decline of oil prices in 1986 forced the government to further promote non-oil exports. The deregulation package of May 1986 was promulgated specifically to reduce import duties for the raw materials of export-oriented goods. In order to raise the

\footnotetext{
1 For detailed accounts of the reform measures introduced in the 1980s and 1990s, see Pangestu (1989), Anwar, et al. (1991), and Surveys of Recent Developments in the Bulletin of Indonesian Economic Studies.
} 
competitiveness of its manufactured goods in the world market, the government also devalued the Rupiah by 45 percent against the US dollar in September 1986. Unlike the previous devaluations (1978 and 1983), the 1986 devaluation was considered successful in terms of increasing non-oil exports due to inflation control and deregulation measures were undertaken. Furthermore, in the reform package introduced in October 1986, many nontariff barriers (NTBs) were removed and replaced by tariffs.

To further promote efficiency, innovation, and productivity, the government introduced several deregulation packages in 1987. The deregulation packages in January and October 1987 attempted to change the import system from an approved importer's system to a general importer's system. The July 1987 deregulation simplified textile quota allocations in order to promote textile and garment exports. In December 1987, export licenses were eliminated, except for some commodities that fall under international or bilateral quotas, e.g., coffee and textile.

In June 1987, the government took a significant step towards financial liberalization by waiving additional approval for investment renewals and expansions of less than 30 percent in capacity. In addition, several sectors that had previously been closed to foreign investors under the investment priority list were opened to foreign investors on the condition that they be export oriented. Trade was further deregulated n November 1988: import monopolies in the steel and plastic industries were removed, and foreign investors, through joint venture with domestic entrepreneurs, were allowed to enter domestic distribution.

Several additional reform measures were launched in the early 1990s, though the pace was not as intensive as in previous periods. In May 1990, export monopolies were removed in several agricultural commodities, e.g., coffee. Then, in June 1991, the government eliminated the need for export licenses for several agricultural products. On the financial side, the government permitted 100 percent foreign ownership of firms beginning in April 1992. This was followed by a further simplification of foreign investment procedures in October 1993. 


\section{Data and Method}

This study relies extensively on the Indonesian national Input-Output (I-O) tables for 1985, 1990, and 1995, which were compiled by the Indonesian Central Bureau of Statistics (CBS, 1989, 1995, and 1998). This study investigates the sources of output growth in Indonesia between 1985 and 1995 from the demand side by using the growth-factor decomposition method. Section 3.1 explains the I-O tables used, while Section 3.2 describes the growth-factor decomposition method, which was developed by Chenery and Syrquin (1979) and has since been employed by many researchers to analyze the sources of output growth on both national and regional levels. ${ }^{2}$

\subsection{Data}

The Indonesian Central Bureau of Statistics has constructed six national I-O tables for 1971, 1975, 1980, 1985, 1990, and 1995. Using the first four national I-O tables, Akita (1991) examined the sources of output growth between 1971 and 1985. This study extends his research to the period between 1985 and 1995 using the 1985, 1990, and 1995 tables. These three competitive import I-O tables utilize producer's prices.

The I-O analysis in this study is based on 37-sector I-O tables; however, to clarify the overall trends in the industrialization process and structural changes, the results are presented using the 16-sector classification given in Table 1. In order to examine real as opposed to nominal changes, this study converted the original current price I-O tables into constant 1983 prices by using industrial GDP deflators. ${ }^{3}$

\subsection{Growth-Factor Decomposition Method}

The growth-factor decomposition method used in this study is based on the following supply-demand balance equation for the national I-O accounts:

$$
\mathbf{X}=\mathbf{W}+\mathbf{D}+\mathbf{E}-\mathbf{M}
$$

\footnotetext{
${ }^{2}$ See, for example, Akita (1991, 1992, and 1994), Chenery (1980 and 1986), Chenery and Syrquin (1979), Feldman, McClain, and Palmer (1987), Holland and Cooke (1992), James and Fujita (1989), Kubo, Robinson, and Syrquin (1986), Lee and Schluter (1993), Martin and Holland (1992), Poot, Kuyvenhoven, and Jansen, (1990), Rose and Casler (1996), Skolka (1989), Sonis, Hewings, and Guo (1996), and Urata (1987).
} 
where $\mathbf{X}, \mathbf{W}, \mathbf{D}, \mathbf{E}$, and $\mathbf{M}$ are vectors of gross output, domestic intermediate demand, domestic final demand, exports, and imports, respectively. Each element of the vectors designates an industrial sector of the Indonesian economy.

If we let $\mathbf{W}=\mathbf{A X}$ and $\mathbf{M}=\hat{\mathbf{m}}(\mathbf{W}+\mathbf{D})$, where $\mathbf{A}$ is a matrix of technical coefficients and $\hat{\mathbf{m}}$ is a diagonal matrix of import ratios (= import/total domestic demand), then we can rewrite equation (1) as

$$
\begin{aligned}
\mathbf{X} & =(\mathbf{I}-\hat{\mathbf{m}})(\mathbf{A X}+\mathbf{D})+\mathbf{E} \\
& =\hat{\mathbf{p}}(\mathbf{A X}+\mathbf{D})+\mathbf{E}
\end{aligned}
$$

where $\hat{\mathbf{p}}$ is a diagonal matrix of domestic supply ratios $(=\mathbf{I}-\hat{\mathbf{m}})$.

Now solving equation (2) for $\mathbf{X}$, we obtain gross domestic outputs necessary to satisfy a specific level of domestic final demand and exports:

$$
\begin{aligned}
\mathbf{X} & =(\mathbf{I}-\hat{\mathbf{p}} \mathbf{A})^{-\mathbf{1}}(\hat{\mathbf{p}} \mathbf{D}+\mathbf{E}) \\
& =\mathbf{B}(\hat{\mathbf{p}} \mathbf{D}+\mathbf{E})
\end{aligned}
$$

where $\mathbf{B}=(\mathbf{I}-\hat{\mathbf{p}} \mathbf{A})^{-\mathbf{1}}$ (which is termed the domestic Leontief inverse).

Equation (3) can be used to solve for the change in gross outputs, $\Delta \mathbf{X}$, in terms of changes in domestic and export demands and changes in the two structural parameters, $\hat{\mathbf{p}}$ and A:

$$
\begin{aligned}
\Delta \mathbf{X} & =\mathbf{X}_{\mathbf{t}}-\mathbf{X}_{\mathbf{0}} \\
& =\mathbf{B}_{\mathbf{t}}\left[\hat{\mathbf{p}}_{\mathbf{t}} \Delta \mathbf{D}+\Delta \mathbf{E}+\Delta \hat{\mathbf{p}}\left(\mathbf{A}_{\mathbf{0}} \mathbf{X}_{\mathbf{0}}+\mathbf{D}_{\mathbf{0}}\right)+\hat{\mathbf{p}}_{\mathbf{t}} \Delta \mathbf{A} \mathbf{X}_{\mathbf{0}}\right]
\end{aligned}
$$

where subscripts 0 and tesignate the base year and the terminal year, respectively.

The growth-factor decomposition equation (4) is obtained by using the terminal year structural parameters, $\hat{\mathbf{p}}_{\mathbf{t}}$ and $\mathbf{B}_{\mathbf{t}}$, and the base year volume weights, $\mathbf{X}_{\mathbf{0}}$ and $\mathbf{D}_{\mathbf{0}}$. However, we can also obtain a factor decomposition equation based on the base year structural parameters, $\hat{\mathbf{p}}_{\mathbf{0}}$ and $\mathbf{B}_{\mathbf{0}}$, and the terminal year volume weights, $\mathbf{X}_{\mathbf{t}}$ and $\mathbf{D}_{\mathbf{t}}$ as follows:

$$
\Delta \mathbf{X}=\mathbf{B}_{0}\left[\hat{\mathbf{p}}_{0} \Delta \mathbf{D}+\Delta \mathbf{E}+\Delta \hat{\mathbf{p}}\left(\mathbf{A}_{\mathbf{t}} \mathbf{X}_{\mathbf{t}}+\mathbf{D}_{\mathbf{t}}\right)+\hat{\mathbf{p}}_{0} \Delta \mathbf{A} \mathbf{X}_{\mathrm{t}}\right]
$$

\footnotetext{
${ }^{3}$ Care should be taken when comparing the results of this study with the results of Akita (1991) since Akita used constant 1973 prices rather than constant 1983 prices. There was a significant change in the price of crude oil between the 1970 s and the 1980 s.
} 
To solve an index number problem presented in (4) and (5), this study uses the simple average of these two equations (4) and (5).

The change in the gross output is thus decomposed into the following four major factors (based on equation (5)):

(a) The expansion of domestic final demand (DD), or the total (direct and indirect) effect on output from each sector of the expansion of domestic final demand in all sectors $\left(\mathbf{B}_{0} \hat{\mathbf{p}}_{0} \Delta \mathbf{D}\right)$;

(b) Export expansion (EE), or the total (direct and indirect) effect on output from each sector of increasing exports in all sectors $\left(\mathbf{B}_{\mathbf{0}} \Delta \mathbf{E}\right)$;

(c) Import substitution (IS), or the total (direct and indirect) effect on output from each sector of increasing the proportion of domestic demand in all sectors that is supplied from domestic production $\left(\mathbf{B}_{\mathbf{0}} \Delta \hat{\mathbf{p}}\left(\mathbf{A}_{\mathbf{t}} \mathbf{X}_{\mathbf{t}}+\mathbf{D}_{\mathbf{t}}\right)\right)$,

(d) Technological change (IO), or the total (direct and indirect) effect on output from each sector of changing technical coefficients throughout the economy $\left(\mathbf{B}_{\mathbf{0}} \hat{\mathbf{p}}_{\mathbf{0}} \Delta \mathbf{A} \mathbf{X}_{\mathbf{t}}\right)$.

Output growth due to the expansion of domestic final demand (DD) can be further decomposed into four components in terms of domestic final demand sectors: household consumption expenditure (DD1); government consumption expenditure (DD2); capital formation (DD3); and change in inventory (DD4). Thus, equations (4) and (5) can be written as:

$$
\Delta \mathbf{X}=(\mathrm{DD} 1+\mathrm{DD} 2+\mathrm{DD} 3+\mathrm{DD} 4)+\mathrm{EE}+\mathrm{IS}+\mathrm{IO} .
$$

\section{Empirical Results}

\subsection{Changes in Industrial Structure}

Since the decline of oil prices in 1982, the Indonesian government, recognizing the disadvantages of relying on oil as the main source of national revenue, has undertaken several reform measures designed to diversify the economic structure. By using I-O tables, this section will examine the changes in the industrial structure.

Table 2 presents the changes in industrial structure in value added, imports, and exports at constant 1983 prices. The share of the agricultural sector in value added decreased from 22.5 percent in 1985 to 14.9 percent in 1995 , but the agricultural sector 
continued to contribute a significant amount to the economy. The share of the mining sector in value added also decreased significantly from 23.3 percent in 1985 to 11.6 percent in 1995. On the other hand, the manufacturing sector showed a significant increase in its share in value added, from 11.7 percent in 1985 to 20.7 percent in $1995 .{ }^{4}$ The increase in the manufacturing sector's share in value added was driven mainly by the increasing share of food, beverages, and tobacco products (from 3.9 to 6.7 percent) and oil refinery products (from 0.4 to 3.0 percent). Among other manufacturing sectors, textile and wearing apparel, wood products, chemical products, and machinery and metal products also increased their share of total value added. Thus, a structural change from primary goods to manufactured goods occurred between 1985 and 1995.

As Anwar, et al. (1991) observed, the decline in the agricultural sector's share in value added is due, to some extent, to the decline in the growth of the food crops sector ${ }^{5}$ and the banning of log exports (see Table2). On the other hand, the main factor that brought about the increase in the share of the manufacturing sector can be traced to several deregulation measures in trade and foreign direct investment introduced in the late 1980s. These, together with the appreciation of the Japanese yen and the currencies of the Newly Industrialized Economies (NIEs) in East Asia, led to the growth of manufacturing facilities in Indonesia.

The sharp decline in oil prices in 1986 compelled the government to introduce several deregulation measures that affected international trade. The effect of these measures can be seen in the sectoral share of imports and exports in Table 2. The share of the agricultural sector in imports decreased from 5.0 percent in 1985 to 1.5 percent in 1990 and then slightly increased to 2.7 percent in 1995 . The import share of the mining sector fell steadily between 1985 and 1995, from 9.4 percent to 4.4 percent. On the other hand, between 1985 and 1995, the import share of the manufacturing sector increased from 68.9 percent to 74.1 percent. This increase was accounted for mostly by the increasing share of food, beverages, and tobacco (from 1.4 percent to 3.8 percent) and textile and wearing

\footnotetext{
${ }^{4}$ According to Akita (1991), between 1971 and 1985, the manufacturing share in value added was very stable at little more than 10 percent.

${ }^{5}$ Indonesia achieved self-sufficiency in rice in 1985 and gradually eliminated subsidies to the agriculture sector.
} 
apparel (from 1.0 percent to 4.5 percent). It should be noted that chemical products, machinery, and metal products accounted for more than half of all total imports.

Within the sectoral share of exports, the share of the mining sector fell sharply from 67.7 percent in 1985 to 27.3 percent and 20.9 percent in 1990 and 1995 , respectively. Though of a smaller magnitude, the agricultural sector's share in exports also decreased markedly from 5.8 percent in 1985 to 1.4 percent in 1995 . On the other hand, there was a conspicuous increase in the export share of the manufacturing sector from 16.6 percent in 1985 to 52.9 percent in 1995 . This was driven mainly by increases in the export share of oil refinery (from 3.3 to 11.9 percent), food, beverages, and tobacco (from 0.6 to 4.5 percent), textile and wearing apparel (from 2.1 to 11.2 percent), and wood products (from 3.8 to 7.4 percent).

These observations clearly indicate a significant change in Indonesia's trade pattern: from a dependence on the primary sector, especially mining, to a major expansion of the manufacturing sector. Several reform measures in particular, such as the removal of import duties on raw materials and intermediate inputs in export-oriented goods, appear to have contributed significantly to the promotion of non-oil manufactured imports and exports.

Table 3 presents export ratios (exports/output) and import ratios (imports/domestic demand) by sector. The export ratio of the agricultural sector decreased between 1985 and 1995 from 5.4 percent to 1.8 percent. The mining sector's export ratio also decreased from 67.0 percent to 38.7 percent. Meanwhile, the export ratio of the manufacturing sector markedly increased from 10.0 percent in 1985 to 20.0 percent in 1995 . This is mainly attributable to the increasing export ratio of oil refinery, textile and wearing apparel, and wood products.

The manufacturing sector also increased its import ratio between 1985 and 1995 (from 22.1 to 25.5 percent), while the mining sector decreased its import ratio (from 14.8 to 11.6 percent) (see Table 3). The increase in the import ratio of oil refinery and textile and wearing apparel contributed to the increase in the import ratio of the manufacturing sector. As Indonesia has relied heavily on imported capital and intermediate goods, the machinery and metal products and chemical products sectors had very high import ratios: 56.6 and 30.6 percent, respectively, in 1995. 


\subsection{The Sources of Industrial Growth: 1985-95}

Tables 4 and 5 provide the results of the growth-factor decomposition analysis, in which all entries are expressed as a percentage of Indonesia's total output growth.

From 1985-90, the expansion of household consumption (DD1) was the main source of output growth, accounting for 48.2 percent (see Table 4 and 5). The sectors most affected were agriculture (5.8 percent), food, beverages and tobacco (8.6 percent), and services (19.5 percent). The increase in capital formation (DD3) was the second largest contributor to output growth, accounting for 31.2 percent. The next largest contributor was export expansion (EE) at 29.2 percent. Among the manufacturing sectors, export expansion (EE) was a major factor in the output growth of oil refinery (8.6 percent), textile and wearing apparel (5.0 percent), and wood products (3.0 percent). Thus, it is evident that the 1986 devaluation and the subsequent series of deregulation measures after 1986 resulted in a massive inflow of foreign capital, especially in export-oriented industries, and a large increase in manufactured exports. A side effect to this is the negative import substitution effect (-6.0 percent), indicating increases in the import of intermediate goods for the production of export-oriented goods.

The pattern of output growth from 1990-95 was quite similar to the 1985-90 period. The expansion of household consumption (DD1) remained the largest source of output growth, accounting for 52.4 percent. This was followed by the increase in capital formation (DD3) at 22.0 percent and export expansion (EE) at 16.4 percent. However, while the contribution of household consumption (DD1) to output growth increased in comparison to the previous period (52.4 percent versus 48.2 percent), this was not the case for the increase in capital formation (DD3) (22.0 percent versus 31.2 percent) and export expansion (EE) (16.4 percent versus 29.2 percent). This indicates a slowdown in exportoriented investments in this period. Manufactured exports more than quadrupled in the 1985-90 period, but in this period, they grew only 50 percent. Similarly, manufactured imports grew only 50 percent in this period, which contrasted sharply with the 200 percent growth in the previous period. This also indicates a slowdown in export-oriented investments, since export-oriented industries are highly dependent on imported intermediate goods. Finally, it is notable that the effect of import substitution (IS) was positive in this period, in contrast to the last period. 
Among the manufacturing sectors, food, beverages, and tobacco had the largest contribution to total output growth in 1985-90 at 11.6 percent. This was followed by oil refinery (10.7 percent), textile and wearing apparel (6.6 percent), machinery and metal products (6.2 percent), chemical products (3.9 percent), and wood products (3.7 percent). In the 1990-95 period, the contribution of the food, beverages, and tobacco sector increased to 13.5 percent. Thus, among manufacturing sectors, the food, beverages, and tobacco sector remained the largest contributor to Indonesia's total output growth, followed by chemical products (6.2 percent) and machinery and metal products ( 5.6 percent). On the other hand, the oil refinery sector's contribution to total output growth sharply decreased to 0.3 percent. The textile and wearing apparel sector's contribution also decreased (6.6 percent versus 4.7 percent), and it became merely the fourth largest contributor to total output growth among the manufacturing sectors.

Next, it is instructive to examine the growth patterns of each manufacturing sector. In 1985-90, the expansion of household consumption (DD1) was the largest factor in the output growth of food, beverages, and tobacco by accounting for 74 percent of sectoral output growth; this was followed by export expansion (EE) which accounted for 22 percent of the sector's output growth. Chemical products had a similar growth pattern, but the effect of export expansion (EE) had a much larger contribution to sectoral output growth at 51 percent, while the expansion of household consumption (DD1) accounted for 54 percent.

In contrast, export expansion (EE) was the largest contributor to the output growth of the oil refinery, textile and wearing apparel, and wood products sectors at 81,75 , and 80 percent, respectively, of their sectoral output growth. As mentioned before, the government attempted to reduce oil dependence and to promote exports from labor-intensive and resource-intensive manufacturing sectors. The pattern of sectoral output growth in oil refinery, textile and wearing apparel, and wood products in 1985-90 indicates the successful implementation of the policy measures adopted in the 1980s.

In other manufacturing sectors, capital formation (DD3) was the largest contributor to the output growth of the machinery and metal products sector and the iron, steel, and non-ferrous metal products sector by accounting for 73 percent and 41 percent of total sectoral output growth, respectively. Government policies to promote diversification of 
manufactured products seem to have increased the effect of capital formation (DD3) on the output growth of these manufacturing sectors.

In the 1990-95 period, export expansion (EE) was still the largest source of sectoral output growth in the textile and wearing apparel sector at 49 percent. However, its contribution declined substantially from the previous period. The same is true for the wood products sector, in which export expansion (EE) accounted for only 33 percent of sectoral output growth; this is in contrast to a 38 percent contribution of sectoral output growth by capital formation expansion (DD3).

In the food, beverages and tobacco sector, the expansion of household consumption (DD1) was still the largest factor at 80 percent. In contrast, export expansion (EE) became the largest source of sectoral output growth in the machinery and metal products sector at 35 percent. The shift in the main source of output growth in the machinery and metal products from capital formation (DD3) in 1985-90 to export expansion (EE) in 1990-95 indicates the diversification of manufactured exports.

\subsection{Changes in the Pattern of Output Growth over the Past 25 Years}

The patterns of output growth have changed significantly over the past 25 years. These are examined by combining the results of this study with those of Akita (1991), which used the same method to examine the growth patterns from 1971-85. Figure 1 presents a radar chart that shows the changes in the sources of output growth by sector. ${ }^{6}$ In this radar chart, the service sector is excluded in order to better illustrate the changes in the growth pattern; this sector accounted for approximately one-half of total output growth for all periods except from 1971-75. The service sector's contribution to total output growth in each period is $33,52,47,56$, and 52 percent for the $1971-75,1975-80,1980-85,1985-$ 90, and 1990-95 periods, respectively.

The major findings are summarized in Figure 1. First, the agricultural sector's contribution declined significantly from over 14 percent in the 1971-80 period to less than 8 percent in the 1980-95 period. Second, the contribution of the mining and oil refinery sector increased during the first 15 years from 1971 to 1985 (from 6 to 12 percent), but it

\footnotetext{
6 In the figure, the industrial materials sector includes the chemical products, non-metallic mineral products, and the iron/steel/non-ferrous products sectors in Table 1.
} 
substantially decreased in the latter 10 years to 5 percent. A similar pattern is observed for the industrial materials sector - its contribution increased from 4 to 11 percent during the first 15 years from 1971 to 1985; however, during the latter 10 years from 1985 to 1995, it declined to 6-8 percent. Third, though the contribution of the food products sector decreased, it still played a prominent role in output growth by accounting for 12-14 percent of total output growth from 1985 to 1995 . Fourth, the textile products sector exhibited a significant increase in its contribution to total output growth from 1-2 percent in 1971-85 to approximately 5 percent in 1985-95. The wood products and printing sector also exhibited a significant increase from approximately 2 percent to 5 percent, but the increase occurred earlier than the textile sector. Fifth, though the contribution of the machinery and metal products sector declined from 11 percent to 0 percent over 1971-85, it recovered somewhat to 6 percent in the 1985-95. From these observations, it is evident that the role of the agriculture and mining sectors in output growth decreased significantly as the factors contributing to output growth became more diversified.

Figure 2 presents another radar chart, but it illustrated the changes in the sources of output growth by growth factor, i.e., DD, EE, and IS, rather than by sector. First, the contribution of the expansion of household consumption (DD1) decreased from 65 percent in 1971-75 to 41 percent in 1975-80, but it again increased and attained the 52 percent level in 1990-95. Second, the contribution of the expansion of government consumption (DD2) exhibited a declining trend: in 1971-75, it amounted to 19 percent of total output growth, but this decreased to less than 2 percent in 1990-95. It is interesting to note, however, that the combined contribution of DD1 and DD2 has been quite stable at around 52-54 percent since 1975-80. These observations indicate the declining role of the government sector in output growth. Third, except for 1980-85, the increase in capital formation (DD3) has been the second largest contributor to total output growth, accounting for more than 20 percent. The expansion of exports (EE) has also played an important role in output growth. It should be noted, however, that from 1985 to 1995, this expansion was achieved, to a large extent, by the increase in non-oil exports. This is in contrast to the period from 1971 to 1980, which was characterized by an increase in oil exports. Fourth, the growth pattern of the 1980-85 period differs markedly from the other periods: in 198085 , the effect of import substitution (IS) was the second largest contributor to total output 
growth at 27 percent, and the expansion of exports had a slight negative effect. With a precipitous decline in oil prices, quantitative restrictions under the approved importers system were, in fact, increased, rather than decreased, during the 1983 to mid-1986 period. The justification for this was the protection of domestic industries and foreign exchange savings (Anwar, et al., 1991). This resulted in import substitution effects in a number of industries during this period.

It is evident that 1980-85 was a transition period in the Indonesian economic development. Faced with a marked decline in international oil prices and the resulting deterioration of the terms of trade, the government started to introduce a series of reform measures in the middle of the 1980s, including the devaluation of the Rupiah, trade liberalization measures, and investment reforms, as discussed in section 2 . The results of this study indicate that the policy measures chosen by the Indonesian government were quite effective in shifting the Indonesian economy toward a more outward-looking, market-oriented structure based on non-oil exports.

\section{Conclusion}

Indonesia has undergone remarkable structural changes in production and trade since the late 1960s due in large part to the two oil booms in the 1970s and declining oil prices in the 1980s. This paper examined the structural changes and the sources of output growth in Indonesia from 1985 to 1995 from the demand side by using the 1985, 1990, and 1995 input-output tables. It also considered changes in the pattern of output growth over the past 25 years from 1971 to 1995.

In the past three decades, Indonesia seems to have achieved a successful transition from an inward-looking, government-led industrialization based on oil exports to an outward-looking, market-oriented industrialization based on non-oil exports. The turning point was during the 1980-85 period. In 1980-85, international oil prices began to decline, and the government began to introduce a series of reform measures, including the devaluation of the Rupiah, the liberalization of trade and investment, and the privatization of public sector industries. These reform measures were quite effective in changing the structure of the Indonesian economy. 
Major structural changes that occurred from 1985 to 1995 included the declining share of agriculture and mining and the increasing share of manufacturing in value added and trade. In value added, the manufacturing sector's share rose from 12 percent to 21 percent, while agriculture and mining's combined share decreased from 46 percent to 26 percent over the same period. The change was most conspicuous in exports, in which the manufacturing sector's share increased from 17 percent to 53 percent, while the agriculture and mining sectors' combined share decreased from 73 percent to 22 percent. Among the manufacturing sectors, the following sectors' export share significantly increased during the period: oil refinery; food, beverages, and tobacco; textile and wearing apparel; wood products; chemical products; and machinery and metal products.

From 1985 to 1990, the expansion of household consumption was the largest factor in output growth; the second and third largest factors were the increase in capital formation and export expansion, respectively. The 1986 devaluation and a series of reform measures introduced since the middle of the 1980s appear to have resulted in a massive inflow of foreign capital, especially in export-oriented industries, and a large increase in non-oil manufactured exports. The 1990-95 period had a similar growth pattern to the 1985-90 period, in which the expansion of household consumption remained the largest source of output growth, followed by the increase in capital formation and export expansion. However, while the contribution of the expansion of household consumption increased from the previous period, the contributions from the increase in capital formation and export expansion decreased, indicating a slowdown in export-oriented investments in this period. It should be noted that from 1985 to 1995, government consumption's contribution had decreased to a negligible level, signifying the declining role of the government sector in Indonesia's output growth.

The financial crisis that started in 1997 suddenly darkened the optimism and dynamism of the Indonesian economy, and in 1998, Indonesia experienced significant negative growth. The financial crisis exerted an enormous influence not only on the financial sector but also the real sector of the Indonesian economy. It is, thus, critical to understand how and to what extent the crisis had affected the structure and growth of the Indonesian economy. Was the effect so large that it significantly altered the pattern of economic growth? In order to answer these and other questions, the economic structure and 
growth in the past few years must be thoroughly examined to evaluate the possible effects of the financial crisis on future growth pattern. That analysis, however, must await the compilation of the next I-O table. 
Table 1. Sector Classifications

\begin{tabular}{|c|c|}
\hline 16 Sector Classification & 37 Sector Classification \\
\hline 1 Agriculture & $\begin{array}{l}1 \text { Agriculture } \\
2 \text { Forestry } \\
3 \text { Fishery }\end{array}$ \\
\hline 2 Mining & 4 Mining \\
\hline 3 Oil Refinery \& LNG & 18 Oil Refinery \& Liquefied Natural Gas \\
\hline 4 Food/Beverages/Tobacco & $\begin{array}{l}5 \text { Food Manufacturing } \\
6 \text { Beverage } \\
7 \text { Tobacco Manufacturing }\end{array}$ \\
\hline 5 Textile/Wearing Apparel & $\begin{array}{l}8 \text { Manufacturing of Textile } \\
9 \text { Wearing Apparel } \\
\text { 10 Leather Product } \\
11 \text { Footwear }\end{array}$ \\
\hline 6 Wood Products & $\begin{array}{l}12 \text { Sawmill \& Wood Product } \\
13 \text { Furniture \& Fixture }\end{array}$ \\
\hline 7 Paper/Printing/Publishing & $\begin{array}{l}14 \text { Paper \& Paper Product } \\
15 \text { Printing \& Publishing }\end{array}$ \\
\hline 8 Chemical Products & $\begin{array}{l}16 \text { Industrial Chemical } \\
17 \text { Other Chemical Products } \\
19 \text { Rubber Products } \\
20 \text { Plastic Product }\end{array}$ \\
\hline 9 Non-Metallic Mineral Products & $\begin{array}{l}21 \text { Ceramics \& Earthenware } \\
22 \text { Glass \& Glass Ware } \\
23 \text { Structural Clay } \\
24 \text { Cement \& Limestone } \\
25 \text { Other Nonmetallic Mineral }\end{array}$ \\
\hline 10 Iron/Steel/Non-Ferrous Metals & $\begin{array}{l}26 \text { Basic Iron \& Steel } \\
27 \text { Nonferrous Basic Metal }\end{array}$ \\
\hline 11 Machinery/Metal Products & $\begin{array}{l}28 \text { Fabricated Metal Products } \\
29 \text { Non-electrical Machinery } \\
30 \text { Elec. Machine/Apparatus } \\
31 \text { Transport Equipment } \\
32 \text { Scientific Equipment/Optical goods }\end{array}$ \\
\hline 12 Other Manufacturing & 33 Other Manufacturing \\
\hline 13 Elec./Gas/Water & 34 Elec./Gas/Water \\
\hline 14 Construction & 35 Construction \\
\hline 15 Trade & 36 Trade \\
\hline 16 Services & 37 Public and Other Services \\
\hline
\end{tabular}


Table 2. Industrial Structure of Value Added, Imports, and Exports at 1983 Constant Prices

in $\%$

\begin{tabular}{|c|c|c|c|c|c|c|c|c|c|}
\hline \multirow[b]{2}{*}{ Sector } & \multicolumn{3}{|c|}{ Value Added } & \multicolumn{3}{|c|}{ Exports } & \multicolumn{3}{|c|}{ Imports } \\
\hline & 1985 & 1990 & 1995 & 1985 & 1990 & 1995 & 1985 & 1990 & 1995 \\
\hline 1 Agriculture & 22.5 & 17.6 & 14.9 & 5.8 & 2.2 & 1.4 & 5.0 & 1.5 & 2.7 \\
\hline 2 Mining & 23.3 & 14.0 & 11.6 & 67.7 & 27.3 & 20.9 & 9.4 & 5.8 & 4.4 \\
\hline 3 Oil Refinery \& LNG & 0.4 & 4.6 & 3.0 & 3.3 & 19.7 & 11.9 & 3.1 & 3.5 & 4.6 \\
\hline 4 Food/Beverages/Tobacco & 3.9 & 5.4 & 6.7 & 0.6 & 5.1 & 4.5 & 1.4 & 2.5 & 3.8 \\
\hline 5 Textile/Wearing Apparel & 1.2 & 1.9 & 2.4 & 2.1 & 8.7 & 11.2 & 1.0 & 5.1 & 4.5 \\
\hline 6 Wood Products & 1.0 & 1.7 & 1.2 & 3.8 & 8.7 & 7.4 & 0.0 & 0.1 & 0.1 \\
\hline 7 Paper/Printing/Publishing & 0.4 & 0.6 & 0.9 & 0.1 & 0.6 & 1.9 & 1.8 & 1.6 & 1.6 \\
\hline 8 Chemical Products & 1.5 & 1.5 & 2.3 & 3.6 & 4.9 & 6.4 & 14.6 & 13.9 & 12.6 \\
\hline 9 Non-Metallic Mineral Products & 0.6 & 0.4 & 0.3 & 0.1 & 0.6 & 0.5 & 1.4 & 1.8 & 1.0 \\
\hline 10 Iron/Steel/Non-Ferrous Metals & 0.7 & 0.7 & 0.7 & 2.3 & 2.1 & 1.9 & 5.3 & 5.0 & 5.2 \\
\hline 11 Machinery/Metal Products & 1.9 & 2.5 & 3.0 & 0.7 & 1.6 & 6.3 & 40.1 & 44.2 & 40.4 \\
\hline 12 Other Manufacturing & 0.1 & 0.1 & 0.2 & 0.0 & 0.3 & 0.8 & 0.2 & 0.4 & 0.4 \\
\hline Total Manufacturing & 11.7 & 19.4 & 20.7 & 16.6 & 52.3 & 52.9 & 68.9 & 78.1 & 74.1 \\
\hline 13 Elec./Gas/Water & 0.5 & 0.5 & 0.4 & 0.0 & 0.0 & 0.0 & 0.0 & 0.0 & 0.0 \\
\hline 14 Construction & 6.0 & 6.8 & 8.9 & 0.0 & 0.0 & 0.0 & 0.0 & 0.0 & 0.0 \\
\hline 15 Trade & 11.2 & 11.5 & 16.4 & 4.0 & 7.7 & 12.5 & 0.0 & 0.0 & 2.4 \\
\hline 16 Services & 24.8 & 30.1 & 27.2 & 5.9 & 10.6 & 12.4 & 16.7 & 14.7 & 16.4 \\
\hline Total & 100.0 & 100.0 & 100.0 & 100.0 & 100.0 & 100.0 & 100.0 & 100.0 & 100.0 \\
\hline
\end{tabular}

Source: Central Bureau of Statistic (1989, 1995, and 1998). 
Table 3. Export Ratio and Import Ratio

in $\%$

\begin{tabular}{|c|c|c|c|c|c|c|}
\hline \multirow[t]{2}{*}{ Sector } & \multicolumn{3}{|c|}{ Export Ratio } & \multicolumn{3}{|c|}{ Import Ratio } \\
\hline & 1985 & 1990 & 1995 & 1985 & 1990 & 1995 \\
\hline 1 Agriculture & 5.4 & 2.8 & 1.8 & 3.0 & 1.7 & 3.3 \\
\hline 2 Mining & 67.0 & 46.3 & 38.7 & 14.8 & 14.3 & 11.6 \\
\hline 3 Oil Refinery \& LNG & 12.9 & 47.5 & 41.6 & 7.7 & 12.7 & 21.1 \\
\hline 4 Food/Beverages/Tobacco & 1.0 & 7.3 & 5.0 & 1.4 & 3.4 & 4.2 \\
\hline 5 Textile/Wearing Apparel & 16.6 & 36.9 & 36.2 & 5.4 & 24.0 & 18.1 \\
\hline 6 Wood Products & 38.4 & 58.0 & 46.1 & 0.3 & 1.0 & 1.2 \\
\hline 7 Paper/Printing/Publishing & 2.3 & 7.7 & 18.3 & 25.5 & 18.1 & 15.9 \\
\hline 8 Chemical Products & 19.9 & 23.1 & 18.7 & 38.4 & 43.7 & 30.6 \\
\hline 9 Non-Metallic Mineral Products & 1.5 & 12.3 & 8.1 & 13.5 & 29.6 & 15.1 \\
\hline 10 Iron/Steel/Non-Ferrous Metals & 35.6 & 24.0 & 20.4 & 43.7 & 40.9 & 40.3 \\
\hline 11 Machinery/Metal Products & 3.2 & 5.6 & 17.2 & 55.2 & 60.5 & 56.5 \\
\hline 12 Other Manufacturing & 5.1 & 40.2 & 38.2 & 14.4 & 42.9 & 22.1 \\
\hline Total Manufacturing & 10.0 & 22.6 & 20.0 & 22.1 & 30.4 & 25.5 \\
\hline 13 Elec./Gas/Water & 0.0 & 0.0 & 0.0 & 0.0 & 0.0 & 0.0 \\
\hline 14 Construction & 0.0 & 0.0 & 0.0 & 0.0 & 0.0 & 0.0 \\
\hline 15 Trade & 8.3 & 14.4 & 12.4 & 0.0 & 0.0 & 2.6 \\
\hline 16 Services & 4.3 & 6.2 & 7.1 & 7.2 & 7.8 & 9.0 \\
\hline Total & 13.5 & 14.5 & 13.0 & 10.1 & 14.4 & 12.8 \\
\hline Total (exclude Mining/Oil Refinery) & 5.7 & 9.7 & 9.8 & 10.0 & 14.5 & 12.6 \\
\hline
\end{tabular}

Source: As for Table 2. 
Table 4. Sources of Output Growth (as percentage of total output growth) in 1985-90

in $\%$

\begin{tabular}{lrrrrrrrrr}
\hline Sector & IS & IO & DD1 & DD2 & DD3 & DD4 & EE & Total & G. Rate \\
\hline 1 Agriculture & -0.1 & -5.7 & 5.8 & 0.2 & 0.7 & -0.1 & 2.1 & 2.7 & 1.5 \\
2 Mining & -0.4 & -6.5 & 1.1 & 0.1 & 1.7 & 2.6 & -4.3 & -5.8 & -3.8 \\
\hline 3 Oil Refinery \& LNG & -0.6 & -0.6 & 1.4 & 0.1 & 1.3 & 0.5 & 8.6 & 10.7 & 17.7 \\
4 Food/Beverages/Tobacco & -0.6 & 1.0 & 8.6 & 0.1 & 0.1 & -0.1 & 2.5 & 11.6 & 9.5 \\
5 Textile/Wearing Apparel & -1.6 & 0.5 & 2.6 & 0.0 & 0.1 & 0.0 & 5.0 & 6.6 & 20.8 \\
6 Wood Products & 0.0 & 0.3 & -0.1 & 0.0 & 0.8 & -0.2 & 3.0 & 3.7 & 16.7 \\
7 Paper/Printing/Publishing & 0.3 & 0.5 & 0.6 & 0.1 & 0.1 & 0.1 & 0.4 & 2.2 & 24.4 \\
8 Chemical Products & -0.7 & -0.1 & 2.1 & 0.1 & 0.4 & 0.1 & 2.0 & 3.9 & 10.8 \\
9 Non-Metallic Mineral Products & -0.3 & -0.5 & 0.2 & 0.0 & 0.7 & -0.1 & 0.3 & 0.3 & 2.7 \\
10 Iron/Steel/Non-Ferrous Metals & 0.1 & 0.5 & 0.1 & 0.0 & 0.8 & 0.1 & 0.3 & 1.9 & 13.8 \\
11 Machinery/Metal Products & -0.9 & 0.3 & 1.4 & 0.1 & 4.5 & 0.1 & 0.8 & 6.2 & 13.9 \\
12 Other Manufacturing & -0.1 & -0.1 & 0.1 & 0.0 & 0.0 & 0.0 & 0.2 & 0.1 & 5.3 \\
\hline 13 Elec./Gas/Water & -0.1 & -0.1 & 0.9 & 0.0 & 0.2 & 0.0 & 0.3 & 1.3 & 9.6 \\
14 Construction & 0.0 & -0.2 & 0.5 & 0.1 & 12.1 & 0.0 & 0.2 & 12.6 & 9.7 \\
15 Trade & -0.2 & -1.8 & 3.3 & 0.2 & 4.0 & -0.1 & 3.2 & 8.8 & 9.3 \\
16 Services & -0.7 & 2.8 & 19.5 & 3.1 & 3.5 & 0.1 & 4.8 & 33.1 & 11.6 \\
\hline Total & -6.0 & -9.8 & 48.2 & 4.3 & 31.2 & 3.0 & 29.2 & 100.0 & 8.2 \\
\hline Total (exclude Mining/Oil Refinery) & -5.2 & -2.8 & 48.0 & 4.3 & 29.6 & -0.1 & 26.2 & 100.0 & 9.5 \\
\hline
\end{tabular}

Note: G. Rate is the average annual growth rate of sectoral output 
Table 5. Sources of Output Growth (as percentage of total output growth) in 1990-1995

in $\%$

\begin{tabular}{lrrrrrrrrr}
\hline \multicolumn{1}{c}{ Sector } & IS & IO & DD1 & DD2 & DD3 & DD4 & EE & Total & G. Rate \\
\hline 1 Agriculture & -0.4 & -1.3 & 7.1 & 0.0 & 0.5 & 0.5 & 0.7 & 7.2 & 7.5 \\
2 Mining & 0.1 & 0.9 & 0.7 & 0.0 & 1.5 & 0.4 & 1.0 & 4.5 & 6.6 \\
\hline 3 Oil Refinery \& LNG & -0.4 & -0.7 & 0.9 & 0.0 & 0.8 & -0.1 & -0.1 & 0.3 & 0.7 \\
4 Food/Beverages/Tobacco & -0.2 & 1.3 & 10.8 & 0.0 & 0.1 & 0.8 & 0.6 & 13.5 & 14.3 \\
5 Textile/Wearing Apparel & 0.4 & -0.1 & 2.0 & 0.0 & 0.0 & 0.1 & 2.3 & 4.7 & 14.5 \\
6 Wood Products & 0.0 & 0.0 & 0.5 & 0.0 & 0.7 & 0.1 & 0.6 & 1.9 & 10.0 \\
7 Paper/Printing/Publishing & 0.1 & 0.2 & 0.6 & -0.1 & 0.1 & 0.0 & 0.7 & 1.7 & 16.3 \\
8 Chemical Products & 1.1 & 0.5 & 2.6 & 0.0 & 0.3 & 0.0 & 1.7 & 6.2 & 19.4 \\
9 Non-Metallic Mineral Products & 0.2 & -0.1 & 0.1 & 0.0 & 0.6 & 0.0 & 0.1 & 0.9 & 14.1 \\
10 Iron/Steel/Non-Ferrous Metals & 0.1 & -0.2 & 0.1 & 0.0 & 0.7 & 0.0 & 0.3 & 1.1 & 10.1 \\
11 Machinery/Metal Products & 0.9 & -0.4 & 1.8 & -0.1 & 1.3 & 0.0 & 2.0 & 5.6 & 14.5 \\
12 Other Manufacturing & 0.1 & 0.0 & 0.2 & 0.0 & 0.0 & 0.0 & 0.2 & 0.5 & 30.4 \\
\hline 13 Elec./Gas/Water & 0.0 & -0.4 & 0.7 & -0.1 & 0.1 & 0.0 & 0.2 & 0.5 & 5.8 \\
14 Construction & 0.0 & 0.6 & 0.4 & -0.2 & 11.8 & 0.0 & 0.1 & 12.9 & 13.1 \\
15 Trade & -0.4 & 1.2 & 15.0 & -0.1 & 1.4 & 0.1 & 2.9 & 20.1 & 23.3 \\
16 Services & -0.5 & 3.0 & 8.9 & 2.1 & 1.8 & 0.1 & 3.1 & 18.5 & 8.9 \\
\hline Total & 1.3 & 4.6 & 52.4 & 1.5 & 22.0 & 1.9 & 16.4 & 100.0 & 11.6 \\
\hline Total (exclude Mining/Oil Refinery) & 1.7 & 4.6 & 53.4 & 1.7 & 20.7 & 1.7 & 16.2 & 100.0 & 12.8 \\
\hline
\end{tabular}

Note: G. Rate is the average annual growth rate of sectoral output 


\section{Figure 1}

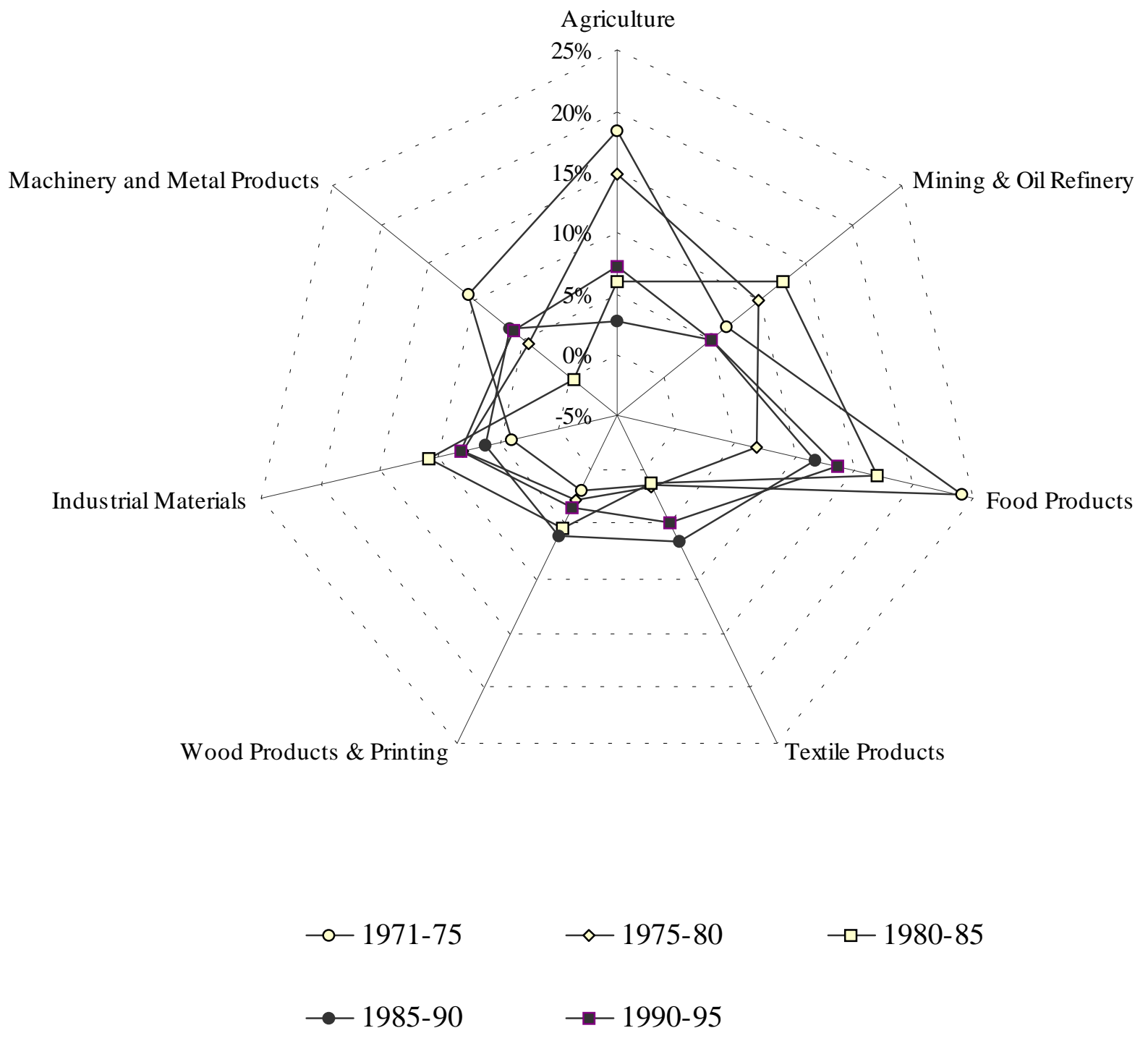


Figure 2

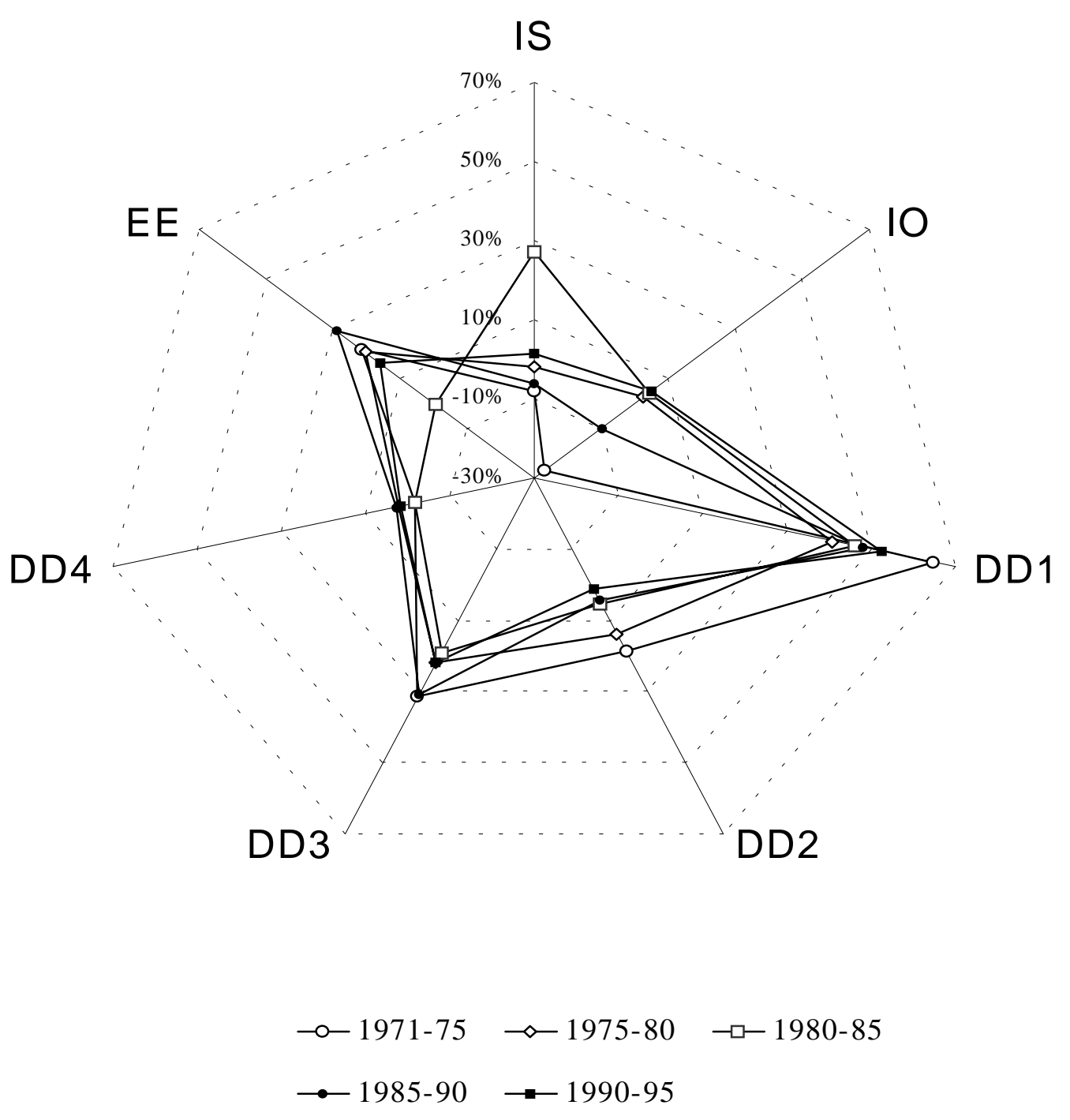




\section{References}

Akita, T. "Industrial Structure and The Source of Industrial Growth in Indonesia: An I-O Analysis Between 1971 and 1985". Asian Economic Journal 5, no. 2 (1991): 139158.

Akita, T. "Sources of Regional Economic Growth in Japan: A Case of Hokkaido Prefecture between 1970 and 1985". Journal of Applied Input Output Analysis 1 (1992): 88-107.

Akita, T. "Interregional Interdependence and Regional Economic Growth in Japan: An Input-Output Analysis". International Regional Science Review 16, no. 3 (1994): 231-248.

Anwar, M.A., Iwan J. Azis, Mari Pangestu, and Hadi Soesastro. "The Indonesian Economy: Problem and Prospect”. Asian Economic Journal 5, no. 2 (1991): 100-138

Central Bureau of Statistics (CBS). Indonesian Input-Output Table 1985. Jakarta: CBS, 1989.

Central Bureau of Statistics (CBS). Indonesian Input-Output Table 1990. Jakarta: CBS, 1995.

Central Bureau of Statistics (CBS). Indonesian Input-Output Table 1995. Jakarta: CBS, 1998.

Chenery, H.B. "Interaction between Industrialization and Exports". American Economic Review 70 (1980): 281-87.

Chenery, H.B. "Growth and Transformation". In Industrialization and Growth: A Comparative Study, edited by H.B. Chenery, S. Robinson and M. Syrquin. New York: Oxford University Press, 1986.

Chenery, H.B. and M. Syrquin. "A Comparative Analysis of Industrial Growth". In Economic growth and resources, edited by R.C.O. Mathews. New York: Macmillan, 1979.

Feldman, S.J., D. McClain and K. Palmer. "Sources of Structural Change in the United States, 1963-78: An Input-Output Perspective". The Review of Economics and Statistics 69 (1987): 503-510.

Holland, D. and S.C. Cooke. "Sources of Structural Change in the Washington Economy: An Input-Output Perspective”. The Annals of Regional Science 26 (1992): 155-170.

James, W.E. and N. Fujita. "Import Substitution and Export Promotion in the Growth of the Indonesian Industrial Sector". ASEAN Economic Bulletin 6, no. 1 (1989): 59-70. 
Kubo, Y., S. Robinson and M. Syrquin. "The Methodology of Multisector Comparative Analysis". In Industrialization and Growth: A Comparative Study, edited by H. Chenery, S. Robinson and M. Syrquin. New York: Oxford Univerity Press, 1986.

Lee, C. and G. Schluter. "Growth and Structural Change in U.S. Food and Fiber Industries: An Input-Output Perspective". American Journal of Agricultural Economics 75 (1993): 666-673.

Martin, R.P. and D. Holland. "Sources of Output Change in the U.S. Economy". Growth and Change 23 (1992): 446-468.

Pangestu, M. "Economic Policy Reforms in Indonesia". The Indonesian Quarterly 17, no. 3 (1989): 218-233.

Poot, H. "Interindustry Linkages in Indonesian Manufacturing". Bulletin of Indonesian Economic Studies 27, no. 2 (1991): 61-89.

Poot, H., Kuyvenhoven, A. and Jansen, J. Industrialization and Trade in Indonesia. Yogyakarta: Gadjah Mada University Press, 1990.

Republic of Indonesia. Policies and prospects for Sustained Development Under Challenging conditions, The Fourth Five Year Development Plan of Indonesia, 1984/1985 - 1988/1989: A Summary. Jakarta: National Development Planning Agency, 1984.

Republic of Indonesia. The Fifth Five-Year Development Plan of Indonesia, 1989/1990 1993/1994: A Summary. Jakarta: National Development Planning Agency, 1989.

Rose, A. and Casler, S. "Input-Output Structural Decomposition Analysis: A Critical Appraisal”. Economic Systems Research 8 (1996): 33-62.

Skolka, J. "Input-Output Structural Decomposition Analysis for Austria". Journal of Policy Modeling 11 (1989): 45-66.

Sonis, M., G.J.D. Hewings and J. Guo. "Sources of Structural Change in Input-Output Systems: A Field of Influence Approach". Economic Systems Research 8 (1996): 1532.

Urata, S. "Sources of Economic Growth and Structural Change in China: 1956-1981". Journal of Comparative Economics 11 (1987): 96-115. 